\title{
Editorial
}

\section{Value-Added Products from Agro-Food Residues}

\author{
Ana Belen Diaz * (D) and Ana Blandino
}

\begin{abstract}
Ana Belen Diaz ${ }^{\circ}$ and Ana Blandino 0
Department of Chemical Engineering and Food Technology, Faculty of Sciences, IVAGRO, University of Cádiz, Campus Universitario de Puerto Real, 11510 Puerto Real, Spain; ana.blandino@uca.es

* Correspondence: anabelen.diaz@uca.es
\end{abstract}

\footnotetext{
check for updates

Citation: Diaz, A.B.; Blandino, A.

Value-Added Products from

Agro-Food Residues. Foods 2022, 11, 766. https://doi.org/10.3390/ foods 11050766

Received: 25 February 2022

Accepted: 26 February 2022

Published: 7 March 2022

Publisher's Note: MDPI stays neutral with regard to jurisdictional claims in published maps and institutional affiliations.
}

Copyright: () 2022 by the authors. Licensee MDPI, Basel, Switzerland. This article is an open access article distributed under the terms and conditions of the Creative Commons Attribution (CC BY) license (https:// creativecommons.org/licenses/by/ $4.0 /)$.
The agri-food sector produces large amounts of waste annually, most of which is lignocellulosic biomass. The growing concern about environmental issues, together with the diminishing of fossil resources, has driven the use of renewable and clean resources for the production of high-added-value products [1]. The use of lignocellulosic biomass for this purpose is promising, given that it represents the most abundant ( 200 billion tons/year) and renewable material in the world. Moreover, it does not compete with food production or animal feed [2]. Traditionally, its use has been limited to being burned for cooking and heating, causing serious environmental impacts such as land degradation and desertification $[3,4]$.

The composition of lignocellulosic biomass is mainly comprised of carbohydrates, generally cellulose $40-60 \%$ and hemicellulose $10-40 \%$, and lignin $15-30 \%$, which are associated in a hetero-matrix and whose relative composition depends on the species, type or source of biomass $[1,5]$. Among these polymers, cellulose represents the core of the complex matrix, which is packed into bundled semi-crystalline microfibers [6]. Given that lignocellulosic biomass is compositionally rich in carbohydrates, it is a suitable resource for the production of bio-based products and chemicals [7].

This Special Issue comprises 10 selected papers in a wide range of related topics, including the pretreatment of lignocellulosic biomass, anaerobic digestion and the production of fermentable sugars and bioactive compounds such as fatty acids, antioxidants, dietary fiber, prebiotics and compounds for food packaging. One of the papers is focused on the application of several pretreatments on exhausted sugar beet pulp, including a biological one, an oxidant pretreatment with alkaline hydrogen peroxide and a thermochemical pretreatment with acid, to solubilize polysaccharides and facilitate the access to cellulose in the subsequent enzymatic hydrolysis for the production of sugars [8]. These sugars were further fermented with Lactobacillus plantarum for the production of lactic acid, a versatile organic acid widely used in the food industry. Despite the high percentage of carbohydrates in the lignocellulosic biomass structure, its recalcitrant structure hinders the access of enzymes and microbes. Thus, the application of a previous pretreatment stage significantly improves the process, as it enables the solubilization of the hemicellulose and lignin fractions, improving cellulose accessibility $[9,10]$.

For the conversion of lignocellulosic biomass into fermentable sugars, a hydrolysis stage is needed, which can be carried out chemically or enzymatically, the latter being more environmentally friendly [11]. In this regard, one of the papers is based on the performance of the hydrolysis of lignocellulosic biomass by the direct addition of the fermented solid obtained by fungal solid-state fermentation as a source of enzymes [12]. The influence of several parameters on reducing the production of sugars was studied, including temperature, the fermented-to-fresh solid ratio, the supplementation of fermented biomass with commercial enzymes and the use of high-solid, batch-fed hydrolysis. With the proposed strategy, the enzyme extraction and purification stages can be avoided.

In another paper included in the Special Issue, an extrusion pretreatment with alkali was applied to vegetal tomato plant waste to concentrate the carbohydrate fraction and 
improve the enzymatic digestibility [13]. During extrusion, the biomass is subjected to heating, mixing and shearing stresses, which cause chemical and physical changes and have potential to improve enzymatic hydrolysis and anaerobic digestion for sugars and methane production, respectively [14]. In another paper in this Special Issue, several additives generated from different activity sectors in agriculture and industry were selected to enhance and stabilize the start-up of the semi-continuous anaerobic digestion of food waste [15]. It is known that this process shows many technical and economic limitations, given that food waste contains easily degradable components, which produce acidification, with weak buffer capacity, resulting in process inhibition. In this respect, the use of co-substrates represents an interesting approach [16]. The results shown in this paper demonstrated that both agricultural and industrial waste were very efficient at improving the anaerobic digestion of food waste or improving the quality of the effluent from the anaerobic digestion [15].

In addition to carbohydrates, agro-food residues are also an important source of natural bioactive compounds with high biological significance and economically feasible production. So, in one paper included in this Special Issue, the level of fatty acids, carotenoids and tocopherols were determined in apple seeds of different geographical origins and from different varieties of Norwegian cultivars [17]. This biomass has turned out to be a good source of fatty acids, linoleic acid, oleic acid and palmitic acid being dominant. Given its composition, the oil of apple seeds seems to have promise as an edible oil.

The residue generated from the processing of Tacinga inamoena (cumbeba) fruit pulp is also a source of bioactive compounds, which has been used as a raw material in another paper included in this Special Issue for the extraction of flavonoids, anthocyanins and betalains [18]. Convective drying was applied to the residue, which has turned out to be even better than freeze-drying for preservation until use and prevents the interference of water during the extraction process, improving the efficiency of the extraction of bioactive compounds. So, this paper also aims to study the influence of temperature and the drying method used to select the best mathematical model to calculate the drying rate, the effective diffusivity and the activation energy.

Another paper of this Special Issue is focused on the use of artichoke crop residues as raw materials for the production of valuable compounds, specifically phenols and inulin [19]. Inulin is a natural storage polysaccharide in plants that is considered a prebiotic compound which is indigestible by humans but stimulates the growth and activity of specific microorganisms of the colon [20]. In the processing of artichoke, large amounts of waste biomass (80-85\%) are generated which are unsuitable for human consumption [21,22]. However, given that this residue includes beneficial compounds, the authors propose a sequential microwave extraction process inspired by green extraction techniques and solvents so that the extracts can be directly used for humans and animals.

In addition to inulin, xylooligosaccharides (XOS), which are composed of sugar oligomers of xylose units, are other prebiotics that can be obtained from agro-food residues [23]. The use of lignocellulosic biomass as raw material for their production is promising, given that it contains a large amount of xylan. So, in another paper of this Special Issue, XOS were produced by liquid hot water (LHW) treatment of the tropical hardwood Eucalyptus pellita, evaluating the influence of reaction temperature, time and $\mathrm{pH}$ [24]. LHW has shown to be more efficient than conventional processes, with higher cost and longer hydrolysis time required for xylanase utilization [25].

Inulin, xylooligosaccharides, beta-glucans, etc., belong to the 'dietary fiber' group, which shows a carbohydrate complex structure that escapes digestion and absorption in the upper human gastrointestinal tract, promoting health benefits to consumers [26,27]. This Special Issue includes a review of the methods used for dietary fiber fractionation to isolate starch and protein and obtain the fiber as a resulting product [28]. Moreover, the review provides a deep characterization based on the fiber's structural, physicochemical and rheological properties. Finally, the paper describes the potential of defatted oilseeds 
(seeds whose fat contents have been removed partially or fully to subsequently improve the protein fraction) as a source of dietary fiber.

Recently, lignocellulose has also shown great potential for chemical cellulose modification and the use of its derivatives, such as nanocellulose, as additives and viscosity modifiers in food, pharmaceuticals, cosmetics and the development of thermoplastic polymers, among others [29]. In this regard, one of the papers of this Special Issue aims to develop films for food packaging with polyvinyl alcohol (synthetic biopolymer) reinforced with lignocellulose nanofibers obtained by the mechanical and chemical pre-treatment of woody residues from tomato, eggplant and pepper plants. The reinforced films showed better properties, including thermal resistance, mechanical parameters, water vapor permeability, UV blocking, antioxidant activity, etc.

Author Contributions: A.B. and A.B.D. have prepared, checked and revised this manuscript. Both authors of the papers included in the collection have substantially contributed and approved for the publication of this Special Issue. All authors have read and agreed to the published version of the manuscript.

Funding: This research was funded by "Ministerio de Economía, Industria y Competitividad", "Agencia Estatal de Investigación (AEI)" and "Fondo Europeo de Desarrollo Regional (FEDER)" (CTM2016-79071-R).

Acknowledgments: We want to thank the authors who contributed towards this Special Issue, as well as the reviewers who provided the authors with comments and very constructive feedback.

Conflicts of Interest: The authors declare no conflict of interest.

\section{References}

1. Wu, X.; Luo, N.; Xie, S.; Zhang, H.; Zhang, Q.; Wang, F.; Wang, Y. Photocatalytic transformations of lignocellulosic biomass into chemicals. Chem. Soc. Rev. 2020, 49, 6198-6223. [CrossRef] [PubMed]

2. Sindhu, R.; Binod, P.; Pandey, A. Biological pretreatment of lignocellulosic biomass-An overview. Bioresour. Technol. 2016, 19, 76-82. [CrossRef] [PubMed]

3. Lynd, L.R.; Sow, M.; Chimphango, A.F.A.; Cortez, L.A.A.; Brito Cruz, C.H.; Elmissiry, M.; Laser, M.; Mayaki, I.A.; Moraes, M.A.F.D.; Nogueira, L.A.H.; et al. Bioenergy and african transformation. Biotechnol. Biofuels 2015, 8, 18. [CrossRef] [PubMed]

4. Ahmad, E.; Suvra, T.; Alam, I.; Pant, K.K.; Haider, M.A. Understanding reaction kinetics, deprotonation and solvation of brønsted acidic protons in heteropolyacid catalyzed synthesis of biorenewable alkyl levulinates. Chem. Eng. J. 2020, 400, 125916. [CrossRef]

5. Bajpai, P. Structure of lignocellulosic biomass. In Pretreatment of Lignocellulosic Biomass for Biofuel Production. SpringerBriefs in Molecular Science; Springer: Singapore, 2016; pp. 7-12.

6. Agbor, V.B.; Cicek, N.M.; Sparling, R.; Berlin, A.; Levin, D.B. Biomass pretreatment: Fundamentals toward application. Biotechnol. Adv. 2011, 29, 675-685. [CrossRef]

7. Kim, J.S.; Lee, Y.Y.; HyunKim, T. A review on alkaline pretreatment technology for bioconversion of lignocellulosic biomass. Bioresour. Technol. 2016, 199, 42-48. [CrossRef]

8. Marzo, C.; Díaz, A.B.; Caro, I.; Blandino, A. Effect of several pretreatments on the lactic acid production from exhausted sugar beet pulp. Foods 2021, 10, 2414. [CrossRef]

9. Bhatia, S.K.; Jagtap, S.S.; Bedekar, A.A.; Bhatia, R.K.; Patel, A.K.; Pant, D.; Banu, J.R.; Rao, C.V.; Kim, Y.; Yang, Y. Recent developments in pretreatment technologies on lignocellulosic biomass: Effect of key parameters, technological improvements, and challenges. Bioresour. Technol. 2020, 300, 122724. [CrossRef]

10. Saikku, L.; Soimakallio, S.; Pingoud, K. Attributing land-use change carbon emissions to exported biomass. Environ. Impact Assess. Rev. 2012, 37, 47-54. [CrossRef]

11. Cooray, S.T.; Chen, W.N. Valorization of brewer's spent grain using fungi solid-state fermentation to enhance nutritional value. J. Funct. Foods 2018, 42, 85-94. [CrossRef]

12. Marzo, C.; Díaz, A.B.; Caro, I.; Blandino, A. Conversion of exhausted sugar beet pulp into fermentable sugars from a biorefinery approach. Foods 2020, 9, 1351. [CrossRef]

13. Moreno, A.D.; Duque, A.; González, A.; Ballesteros, I.; Negro, M.J. Valorization of greenhouse horticulture waste from a biorefinery perspective. Foods 2021, 10, 814. [CrossRef] [PubMed]

14. Duque, A.; Manzanares, P.; Ballesteros, M. Extrusion as a pretreatment for lignocellulosic biomass: Fundamentals and applications. Ren. Energy 2017, 114, 1427-1441. [CrossRef]

15. Chaher, N.E.; Nassour, A.; Hamdi, M.; Nelles, M. Monitoring of food waste anaerobic digestion performance: Conventional co-substrates vs. unmarketable biochar additions. Foods 2021, 10, 2353. [CrossRef] [PubMed] 
16. Akturk, A.S.; Demirer, G.N. Improved Food Waste Stabilization and Valorization by Anaerobic Digestion Through Supplementation of Conductive Materials and Trace Elements. Sustainability 2020, 12, 5222. [CrossRef]

17. Akšić, M.F.; Lazarević, K.; Šegan, S.; Natić, M.; Tosti, T.; Ćirić, I.; Meland, M. Assessing the fatty acid, carotenoid, and tocopherol compositions of seeds from apple cultivars (Malus domestica Borkh.) grown in Norway. Foods 2021, 10, 1956. [CrossRef]

18. de Lima, J.P.; de Melo, A.J.; Feitosa, R.M.; Pereira, W.; Palmeira, J.; da Costa, D.; Araujo, H.; Trindade, A.P.; Costa, A.C.; Gomes, A.C.; et al. Utilization of Cumbeba (Tacinga inamoena) residue: Drying kinetics and effect of process conditions on antioxidant bioactive compounds. Foods 2021, 10, 788.

19. Francavilla, M.; Marone, M.; Marasco, P.; Contillo, F.; Monteleone, M. Artichoke biorefinery: From food to advanced technological applications. Foods 2021, 10, 112. [CrossRef]

20. Singh, R.S.; Singh, T.; Larroche, C. Biotechnological applications of inulin-rich feedstocks. Bioresour. Technol. 2019, 273, 641-653. [CrossRef]

21. Zuorro, A.; Maffei, G.; Lavecchia, R. Reuse potential of artichoke (Cynara scolimus L.) waste for the recovery of phenolic compounds and bioenergy. J. Clean. Prod. 2016, 111, 279-284. [CrossRef]

22. Rabelo, R.S.; Machado, M.T.C.; Martínez, J.; Hubinger, M.D. Ultrasound assisted extraction and nanofiltration of phenolic compounds from artichoke solid wastes. J. Food Eng. 2016, 178, 170-180. [CrossRef]

23. Vázquez, M.; Alonso, J.; Domínguez, H.; Parajó, J. Xylooligosaccharides: Manufacture and applications. Trends Food Sci. Technol. 2000, 11, 387-393. [CrossRef]

24. Jang, S.K.; Kim, J.H.; Choi, J.H.; Cho, S.M.; Kim, J.C.; Kim, H.; Choi, I.G. Evaluation of Xylooligosaccharides production for a specific degree of polymerization by liquid hot water treatment of tropical hardwood. Foods 2021, 10, 463. [CrossRef] [PubMed]

25. Brienzo, M.; Carvalho, W.; Milagres, A.M. Xylooligosaccharides production from alkali-pretreated sugarcane bagasse using xylanases from Thermoascus aurantiacus. Appl. Biochem. Biotechnol. 2010, 162, 1195-1205. [CrossRef] [PubMed]

26. Hussain, S.; Jõudu, I.; Bhat, R. Dietary fiber from underutilized plant resources-A positive approach for valorization of fruit and vegetable wastes. Sustainability 2020, 12, 5401. [CrossRef]

27. Asp, N.G. Definition and analysis of dietary fibre. Scand. J. Gastroenterol. 1987, 22, 16-20. [CrossRef]

28. Nevara, G.A.; Muhammad, S.K.S.; Zawawi, N.; Mustapha, N.A.; Karim, R. Dietary Fiber: Fractionation, characterization and potential sources from defatted oilseeds. Foods 2021, 10, 754. [CrossRef]

29. Morcillo-Martín, R.; Espinosa, E.; Rabasco-Vílchez, L.; Sanchez, L.M.; de Haro, J.; Rodríguez, A. cellulose nanofiber-based aerogels from wheat straw: Influence of surface load and lignin content on their properties and dye removal capacity. Biomolecules 2022, 12, 232. [CrossRef] 